\title{
Reinventing Government and the Separation of Powers
}

\author{
BY ISTVÁN STUMPF*
}

\begin{abstract}
Challenges caused by the global economic crisis in connection with the structural, political changes transformed the construction, the nature, and the operation of the executive branch. During the last decades in the separation of powers' system the state had been rediscovered and governmental power had been appreciated.

In a world covered with the internet, financial, economic and political crisis situations appeared; governments and governmental centres had to give sufficient answers to global challenges. The world under the pressure of the media changed the daily routine of the governmental work: beside the good decision-making, carrying the governments' point across parliaments and public opinion too became increasingly significant. Strengthening the symbiosis between the legislative and executive branch in parliamentary governmental systems can be observed. Members of the governing party attending the rigorous party discipline are decreasingly able to function as democratic control. These members rather become patronisers ('voting machines') of the governmental intention without critical voices. The personality of the politicians coming to the front and the marketability of the politics in the media also strengthened the process which resulted in the intensity of the Prime Minister's role within the executive branch. Increasing the role of the Prime Minister and governmental central bodies lead to the weakening of the government's corporative character, and the government's gaining ground opposed to the Parliament. According to international examples in significant western European parliamentary democracies (for example: United Kingdom: Margaret Thatcher and Tony Blair, Italy: Silvio Berlusconi, Sweden: Göran Persson) the role of the Prime Minister (as the head of the government) also appreciably strengthened. Beside this attitude, the outsourcing of each governmental function (good governance), the sufficiency of state's strengthening (good government), and making governmental public services available electronically (e-government) are also under hard discussion.

The aim of this paper is to review - based on new constitutional and other changes of public law - the centralization of the head of the Hungarian government; the strengthening of the 'chancellor-principle' by the Hungarian Fundamental Law; and the process that lead to the Prime Minister's Office becoming 'top chancery'. The paper takes into consideration the transformation of the separation of powers' system and the strengthening of the Prime Minister's role within the executive branch and its affect on the Hungarian administrative system.
\end{abstract}

Keywords: government and governance, Fundamental Law, separation of powers, centralisation of public administration, presidentialisation, political responsibility, principle of confidence, central administrative bodies

\section{REINVENTING GOVERNMENT AND THE SEPARATION OF POWERS}

The global social and financial challenges within the narrowing national margin demanded the strengthening of governmental activities for national strategic goals. Financial, economical, and political crises have appeared at an unbelievable rate in the "interconnected" world, meaning that it was necessary for governments' to have a quick response. All of these processes placed the quick decision making ability and effectiveness of governmental centres in the spotlight. The media-centred world changed the government's casual work; besides making good decisions it became increasingly important to make parliaments as well as the general public accept these decisions. Proactive communication became an integral part of governing and frequent media coverage became a basic requirement for politicians. In parliamentary systems strengthening the symbiosis between the legislative and the executive branches can be detected. Those governing party MP's who followed

* Judge of the Hungarian Constitutional Court, professor at the Széchenyi István University in Győr. E-mail: stumpf@mkab.hu 
the strict party discipline were hindered in their ability to fulfil the role of democratic control. This resulted in becoming the unquestioning supporters of government aims, like the "voting machine". The "personification" (bringing the personality of politicians to the fore) and "mediatisation" (making politics a good product for selling in the media) of politics further enhanced the processes that led to the presidentialisation ${ }^{1}$ of the executive power. The Increasing role of the Prime Minister and the governmental centre resulted in weakening the corporate character of government and in the dominance of government over parliament. Series of international examples have shown how in western European parliamentary democracies (e.g. Margaret Thatcher and Tony Blair in Great Britain, Silvio Berlusconi in Italy, Göran Persson in Sweden) the Prime Minister's role have increased. In addition to presidentialisation there were heated debates about outsourcing and marketisation of certain government tasks (good governance), and the necessity of strengthening the role of the state (good government). ${ }^{2}$ The digitalisation of social and economic processes and the information society changed everyday life resulting in the establishment of electronic administration (e-government). Without analysing and taking in account these developments the research of the constitutional role of government would be incomplete.

\section{THE CHANGE OF THE CONSTITUTIONAL FRAMEWORK OF THE HUNGARIAN GOVERNMENT}

The Fundamental Law of Hungary did not bring along significant changes with regards to the position of the government within the state system: the government system of Hungary remained a parliamentary republic. The principle of the separation of powers is enshrined in the Fundamental Law. Additionally, the structural and political changes which occurred since the Hungarian transition transformed the structure, the nature and the functioning of the executive branch are also included in the Fundamental Law. In order to analyse the constitutional position of the Government, it is necessary to show first the processes that resulted in the rediscovering of the state and also resulted in the rise of governmental powers during the last decades.

Regarding the constitutional status ${ }^{3}$ of the executive power and the government the Fundamental Law - continuing the tradition of the last 20 years - took the position of continuity. The state system of Hungary is still characterised by the parliamentary type of government, together with the responsibility of the executive power given to the Parliament. However, unlike the previous constitution, the above cited Article 15 of the Fundamental

1 On the level of the executive power the "presidentialisation" of politics means the strengthening of the Prime Minister's power, and the weakening of the corporate character of the Government. The stronger power of the heads of government means that numbers of areas under their direct control are increasing, and also their ability strengthens by which they can successfully resist political players having different views. On this topic see: Poguntke et al. (2005) 4-6.

2 See in detail: Stumpf (2014) 104-107.

3 The most important sources of law defining the status of the Hungarian Government are the following: Articles 15-23 of the Fundamental Law, Act XLIII of 2010 on the central administrative bodies and the status of undersecretaries (Ksztv.), Act XX of 2014 on the list of ministries, furthermore: Act XXXVI of 2012 on the National Assembly, Act CXIX of 2011 on administrative officials, Act CXXVI of 2010 on the Capital and County Government agencies, and the Acts of each administrative body. 
Law defines the position and function of the government within the whole constitutional system. ${ }^{4}$ Compared to the Constitution, defining the constitutional role of the government is a step forward, yet the Fundamental Law still does not give a substantial definition of the executive power, for example the classic role of executing legal acts, which derives from the function of the government.

The Government has received a double function with regards to its constitutional position. First, the government is the general body of the executive branch, with a large scale of powers, positioned at the head of the public administration, being responsible for its actions. Secondly, in a broad sense, the government is the decision making centre of the whole political system, its governing role, besides its enforcement role, also includes the political control of the legislative. The role of governing is political natured, but government has legally regulated power, therefore it carries out its executive-regulative activities within constitutional boundaries. The power of the government can encompass all matters which are not expressly assigned by the Fundamental Law or a rule of law to the tasks and competences of another organ. Due to the separation and functional division of powers the primary responsibility of the executive branch is to carry out and enforce the execution of political decisions - acts of parliament, government decrees, and various normative and unique decisions. Political execution consists of at least three functions: program making, transforming political aims to law, and controlling the administrative execution. ${ }^{5}$ As the central organisation of the administration, government has significant freedom in creating bodies, and wide decision making powers with regards to the issues within its competency. The government has autonomous legislative power when carrying out its functions. The government can adopt decrees under authorization given by an act of Parliament or without authorization. Through the controlling power, ${ }^{6}$ the government has a decisive influence on the top level of public administration, and therefore upon the actions of any subordinated body. This way the government ensures the coordinated actions of the hierarchical system of public administration, as well as the efficient functioning of the modern state.

The fact that the Fundamental Law highlights the governmental functions points to the increased significance of the executive power. Governing is exercising power and par excellence a political activity, therefore much more than the "high command" of public administration. The government has a crucial role in defining state functions and determining the aim and contents of state actions. Governments play a significant role in shaping the work of the Parliament. Through the preparation and submission of laws, the government influences significantly the topics debated by the parliament (legislative program). By submitting the act on annual budget the government defines the priorities of distributing available resources, as well as the main directions of government activities. The need for "good governance" was created by the global challenges that transformed state functions, and the strong demand for serving the public good. Modern governing, the exercising of state powers is increasingly interconnected with the function of managing public services

${ }^{4}$ According to Article 15 paragraph 1 and 2 of the Basic Law: "The Government is the general means of executive power; its tasks and competencies shall encompass all that is not expressly conferred by the Fundamental Law or any other legislation under the competence of another body. The Government shall answer to Parliament. The Government shall be the principal organ of public administration; it may establish government agencies pursuant to provisions laid down by law."

5 Hine (1993) 197.

6 The legal definition of control is given by Art. 2 paragraph 1 of the Ksztv. 
and public bodies. In a constitutional sense the government, as the top of the executive branch, is trusted with leading the state, and enjoys a wide freedom of movement from the Parliament that elected them as well as against the judicial branch.

\section{THE CENTRALISATION OF GOVERNMENT: THE STATUS OF THE PRIME MINISTER, PRESIDENTIALISATION}

The Fundamental Law did not reform the tradition that was formed after the Hungarian political transition, asking the leader of the political party that has the best chance of winning majority support to form a government. In a constitutional sense the President is free to decide, he has no obligation to discuss possibilities with the leaders of the political parties that were in parliament before making his decision (however political rationality would suggest otherwise). Because of the President's obligation to control the democratic functioning of the state, the President is interested in nominating someone for Prime Minister who is likely to be elected by the (super) majority of the Parliament. ${ }^{7}$ According to the Act on the Parliament of Hungary, every state official is elected by a secret voting procedure, except for the Prime Minister, where there is a public vote. As for the time limit of the presidential nomination the Fundamental Law repeats the previous regulations, and also defines new, shorter deadlines. If the mandate of the Prime Minister ceased at the moment of the inaugural meeting of the newly elected Parliament the nomination has to be made at the inaugural meeting. If his mandate is terminated by resigning, death, the declaration of conflict of interest, because of the lack of the conditions mandatory for election, or because the Parliament has voted for no confidence against the Prime Minister, the President is obliged to make his nomination within 15 days after the termination of the Prime Minister's mandate. If the nominated person is not elected by the parliament, the President makes a new nomination within 15 days. If the absolute majority of the Parliament does not fall in line with the nominations, and the Prime Minister is not elected within 40 after the first nomination, the President is entitled to dissolve the Parliament. [Fundamental Law, Art. 3, para. (3), point a)]

The Fundamental Law instituted an important change in connection with the termination of the Prime Minister's mandate. The constitution (Act XX of 1949) stipulated the cases of the termination of the Government's mandate, whereas the Fundamental Law - thus underlining the importance of the constitutional status of the Prime Minister explicitly refers to the cases of the termination of the Prime Minister's mandate, at the same time terminates the government's mandate as well. [Article 20] According to the rules of the Fundamental Law, there are seven cases when the Prime Minister's mandate is terminated: a) after the inaugural meeting of the newly elected parliament, b) if the Parliament elects a new Prime Minister by a constructive motion of no confidence, c) if the Prime Minister fails the vote of confidence initiated by himself, d) by the resignation of the Prime Minister, e) by death, f) by the declaration of conflict of interest, g) if the conditions necessary for his election are no longer met.

The Fundamental Law also stipulates what to do after losing the vote of confidence. Unlike the previous regulation, after losing the vote of confidence, the Government and the

${ }^{7}$ Article 16 paragraph 3 and 4 of the Fundamental Law: "[t]he Prime Minister shall be elected by Parliament on a recommendation by the President of the Republic. A simple majority of votes cast by Members of Parliament shall be required to elect the Prime Minister. The Prime Minister shall take office immediately upon his or her election." 
Prime Minister do not have to resign, but rather their mandates are terminated automatically. In four of the above mentioned cases the Parliament decides the fate of the Prime Minister's mandate. The Fundamental Law, in order to separate different events of termination of the Prime Minister's mandate, sets forth that in cases of the vote of no confidence, the vote of more than half of all members is required, whereas in the cases of point $f$ ) and point g) - demanding a larger majority - the vote of two-thirds of attendant members is needed. The Parliament votes on both the conflict of interest and the lack of requirements needed for election upon the written motion of any member of parliament, within 30 days. The Government, from the termination of its mandate until the formation of a new government, functions as a caretaker government [Article 22]. The former double limitations were upheld; the caretaker government may not recognize the binding force of international treaties and may adopt decrees only in case of urgency and on the basis of express authorization provided by an act of Parliament. The various cases of termination of the Prime Minister's mandate carry different consequences in relation to the question of who should exercise the powers of the Prime Minister. According to the Fundamental Law, if the mandate of the Prime Minister is terminated upon his or her resignation or upon the inauguration of a newly-elected Parliament, the Prime Minister serves as a caretaker Prime Minister until the new Prime Minister is elected. In this case however, he has limited constitutional capacity: he may not propose the dismissal of a minister or the appointment of a new minister, and may issue a decree only in case of urgency and on the basis of express authorization provided by an act of Parliament. In all other cases, except for the case of no confidence, the deputy Prime Minister exercises the powers of the Prime Minister, with the aforementioned limitations, until the new Prime Minister is elected.

The constitutional and political character of the Prime Minister - beyond the previously shown general direction-giving and policy-making role - have been formed by other regulations of the Fundamental Law. The Prime Minister is the defining character of the Government, but he also has powers separate from the Government that he exercises on his own responsibility. Defining the general political direction obviously greatly influence the recruiting and selection of ministers. The Prime Minister may come up against some political boundaries upon changing the composition of the government, but in a constitutional sense there is no limitation to dismissing ministers and appointing new persons. The Fundamental Law defines several competences of the Prime Minister. In comparison with the previous legislation it is a new element that he can define tasks for ministers [Article 18 para. (2)] and he can ask for information from them. Furthermore he can appoint or nominate the leaders of autonomous regulatory bodies, and may appoint a deputy. It is within his traditional powers to issue decrees, give opinions on the dissolution of parliament, take part and speak in parliamentary sessions. The Prime Minister has powers and an obligation to cooperate in times of emergency; he is a member of the National Defence Council assembled in the time of national emergency. As the head of government he chairs government sessions, and has a defining role in organising the work of the government. He represents Hungary and its government in international relations, especially within the European Union.

The gaining of ground of the presidentialisation undoubtedly influences the Prime Minister (chancellor)-type of government functioning. From among the reasons of the international trend of presidentialisation the weakening of traditional ruptures of society, the redefining of the role of the state, one of the most important reasons is the growing significance of mass media in politics. Many scholars believe that the presidentialisation can only occur in parliamentary systems, while others think that it can happen in any system 
of government, even in presidential or semi-presidential systems. In parliamentary democracies the institutional status of the head of government is mainly characterised by the relationship between the legislative and the executive branch, the formal and informal strength of the Prime Ministers position within the government, and the status of the constitutional institutions that are capable of balancing the power of the Prime Minister. ${ }^{8}$

In the Hungarian constitutional system, the constitutional regulations (decision making powers, forms of political responsibility) make the Prime Minister the central figure of state governing. Our parliamentary system is characterised by the German-style "medium strong" governing of the Prime Minister. ${ }^{9}$ The Fundamental Law does not just uphold the Prime Minister-based (chancellor type) government model, but rather strengthens it. ${ }^{10}$ The Fundamental Law explicitly makes it the Prime Minister's right and obligation to define the general politics of the Government (,Richtlinienkompetenz”), formally making him responsible for creating government policy. The Fundamental Law changed the former constitutional regulations stipulating that the Parliament first voted on the person and at the same time the governmental program of the Prime Minister. According to the "new" constitutional order the formation of the government begins with the election of the Prime Minister, and the Government receives the confidence and authorisation to govern from the parliamentary majority by the election of the Prime Minister. Without the support of the parliamentary majority the Prime Minister cannot form a government, and cannot define the general policy. Contrary to the previous regulations the Fundamental Law does not bind the election of the Prime Minister to the adoption of the government program, and does not define substantially what the general government policy means. The rule also cannot be founded which tells when and how the Prime Minister is obligated to show the government's general policy to the public. Thus the Fundamental Law, besides abolishing the vote on the government's general policy, leaves 'place' for the Prime Minister to define the form and substance of the government's policy. Therefore the Prime Minister has received strong legal support to be the political leader of the government, representing the whole government in public and international relations. As the head of the executive power he represents the government policy and significantly influences the functioning of the public administration.

Another important characteristic of the "chancellor-type" government model and one of the most important sources of the Prime Minister's power is the Prime Minister's discretional right to select ministers. This is why a phrase can be created: the government has not gained a leader but rather the Prime Minister has won a government. Selecting and dismissing ministers - of course through the head of state, with respect to party power relations - are the Prime Minister's exclusive tasks. The different form of political responsibility of the Prime Minister and the ministers is one of the main components of the

8 There are several signs of presidentialisation, among which the following should be emphasized: the widening of the powers of the head of Government, the centralisation of political processes and government communication, the strengthening of the oversight competences of the Prime Minister's Office, the strengthening of the influence of background institutions, the exponential multiplication of the Prime Minister's personal advisors, the growing number of technocrats and politicians with no party ties, the growing of financial funds available for the Prime Minister, etc.

9 In international comparison the head of government in Italy has a really weak, and the British Prime Minister has a very strong position.

10 Article 18 paragraph 1 of the Fundamental Law: "The Prime Minister shall define the general policy of the Government". 
Prime Minister's wide range of motions upon appointing and dismissing the members of the government. Of course the range of motions of the Prime Minister is in close connection with his party background and the coalition composition of the government. ${ }^{11}$

The weight of the Prime Minister within the government is further increased by the German-type "constructive" vote of confidence and the lack of parliamentary vote of confidence of individual ministers. Article 18 paragraph 4 of the Fundamental Law defines the responsibility of the government members with regards to the Prime Minister and the Parliament. Unlike the classic rules of "parliamentarism" ministers actually can only have such political responsibility with regards to the Prime Minister which can in fact result in their dismissal. Members of parliament have only weaker tools in order to enforce parliamentary responsibility of government members (question, interpellation, report, and hearing). Therefore the Parliament may only dismiss ministers together with the whole government, which further strengthens the position of the Prime Minister against the Parliament.

\section{THE RELATIONSHIP BETWEEN THE PARLIAMENT AND THE GOVERNMENT: THE IMPORTANCE OF POLITICAL RESPONSIBILITY AND THE PRINCIPLE OF CONFIDENCE}

The Hungarian transition created a parliamentary system of government, in which the role of the Government is fundamental constitutional that depends on the confidence of and is responsible to the majority of the Parliament. According to both the Hungarian and the continental traditions the responsibility of the executive branch towards the Parliament - as the main carrier of people's sovereignty - creates the democratic legitimacy of the Government. In parliamentary systems the government is created by the political parties that have majority in the Parliament, and the close cooperation between the governing parties and the executive branch creates the stability of the government. Political confidence is the key to the relationship between the government and the Parliament. The erosion of political trust may sink government efforts and cause a series of government crises, whereas its presence may secure the governing capability and freedom of action of the government. In parliamentary systems the most important tool that the Parliament has control over is the government, namely the vote of censure. The censure motion against the Government is the most important constitutional sanctioning tool of the Parliament in overseeing the executive power.

It can be clearly read from the regulating concept of the Fundamental Law that the confidence of the Parliament towards the Government is connected to the Prime Minister. ${ }^{12}$

11 In a coalition government the Prime Minister is tied by the coalition agreement, in which the distribution of ministries between the parties is laid down. He has to keep this agreement otherwise he risks the dissolution of the coalition government. If the Prime Minister has to lead a minority government, then it is more possible that in exchange for political support he offers a ministerial position to the opposition. In the case of a one-party government with a strong majority, the Prime Minister's manoeuvring space is widened if he is also the party chairman and he controls the decision making bodies of the party.

12 "The Parliament shall elect the Prime Minister, decide upon questions of confidence relating to the Government;." [Article 1. paragraph 2 of the Basic Law] "Members of the Government shall give account of their activities to Parliament, and ministers shall give account of their activities to the Prime Minister." [Article 18. paragraph 4 of the Fundamental Law.] 
It is demonstrated in the fact that the Parliament expresses its confidence by electing the Prime Minister, and by a censure vote the Government is also overthrown. The vote of confidence expresses certain political opinions, the support of the Prime Minister who represents government policy, giving him authorisation to form a government and define the political direction. The twin sister of political confidence - in a parliamentary system based on the separation of powers - is political responsibility. The government is responsible to the Parliament for its activities, which is exercised in various forms by the Parliament (question, interpellation, report, committee hearing, and investigative committee). The loss of political trust may result in the gravest sanction of political accountability: the dissolution of the Government. The Fundamental Law differentiates between the accountability of the Government as a body and the members of the government, but it does not stipulate the type and basis of accountability. According to the character of parliamentary systems the accountability of the government and its members mean political accountability that is based on the political actions and decisions of the executive branch and the ministers. Members of the Government are also accountable in a legal sense, but these regulations do not differ from the regulations regarding other state officials.

The Fundamental Law - upholding the former constitutional concepts - makes it only possible for the Parliament to express no confidence by its own initiative towards the Government via censure motion. This is the strongest sanctioning tool of the Parliament, originally introduced by Act XL of $1990 .{ }^{13}$ The fundamental part of the constructive motion of no confidence ${ }^{14}$ is that the Parliament may only dismiss the Government if the election of a new Prime Minister occurs at the same time. The Parliament may raise the issue of confidence if at least one-fifth of the members of parliament initiate a motion of no confidence - also indicating the person nominated for Prime Minister - against the current Prime Minister. The motion of no confidence becomes constructive because it may only be initiated along with the nomination of the new Prime Minister. The censure motion may only be directed at the current Prime Minister, and it affects the mandate of the whole Government. For the adoption of the censure vote the vote of the majority of the members of Parliament is needed (absolute majority). In case of a successful ${ }^{15}$ censure motion the mandate of the Prime Minister and that of the Government is terminated and the new Prime Minister is to be considered elected. In the past decades the censure motion helped the stability of the governments after the transition, by preventing the formation of ad hoc political alliances that would have led to long lasting political crises.

13 The German type censure motion was introduced by Prime Minister Antall József in order to retain governability. The MDF-SZDSZ Pact of 29 April 1990 made it possible to pass the necessary amendment of the Constitution. See in detail: Bihari (2005) 395.

14 "A motion of no confidence against the Prime Minister may be introduced in writing - along with the nomination of the candidate for the new Prime Minister - by no less than one-fifth of all Members of Parliament. (...)The Prime Minister may propose a vote of confidence. Parliament is considered to express its lack of confidence in the Prime Minister unless in the vote of confidence proposed by the Prime Minister the majority of Members of Parliament supports the Prime Minister's proposal." [Article 21. paragraph 1 and 3 of the Fundamental Law].

15 International experience shows the diminishing political role of motions of no confidence. In Germany it was only used once, and is has not been used in Hungary until April 2009. Even in this case it was not used as the opposition's tool to replace the Prime Minister, but the governing parties used it as a quick way to replace their - politically failed - Prime Minister without involving the President. 
Alternatively, the censure vote does not mean the Parliament's controlling role over the Government, but rather it is a tool of government dominance over Parliament. Mostly it is used to discipline rogue members of the governing party. Its function is not to enforce political accountability, it is a governing tool in cases when the support of a motion is doubtful, or the re-establishment of trust towards the Government is needed. The Prime Minister may raise the question of confidence in two ways. The first way is when the head of government moves for a censure vote in the Parliament. This mainly happens when the Prime Minister notices the decrease in support of the parliamentary majority, and he wants to measure the presence or absence of confidence. If more than half of the members of Parliament support the Prime Minister and his government, he has won, and can continue working. In the other, more special case, the Prime Minister asks the censure vote in connection with a government motion in the Parliament. In this case the majority needed to win the vote depends on the motion to which it is bound. If only a simple majority is needed to adopt the bill, then a simple majority is enough to uphold confidence. In the - rather rare - case when the Government asks for the censure vote in connection with a motion that requires a two-thirds majority to pass, then the failure may only be avoided by gathering such a majority. The decision on censure motions have to be made no sooner than three, but not later than eight days after the motion. If the Parliament expresses no confidence in a vote initiated by the Prime Minister, then it automatically - ex lege - leads to the termination of the Prime Minister's and the Government's mandate.

\section{STRUCTURE AND FUNCTIONING OF THE GOVERNMENT}

The Fundamental Law does not include the actual functioning ${ }^{16}$ of the government, or its decision making process, such regulations can be found in lower level legislation. The Rules of Procedure ${ }^{17}$ of the Government stipulates that the Government carries out its functions as a body, with the leadership of the Prime Minister. Therefore the debating forum of government members is the government session. The Government, as a body is entitled with the powers associated with legislation, the right to initiate bills, the right to issue decrees and make decisions. The government as a body controls any subordinated bodies, carries out its legal responsibilities, and may give orders to its members, the ministers. The corporate character of the Government has decreased because of the transformation of government activities (presidentialisation, personification, and mediatisation). The Fundamental Law also made changes in a constitutional sense, because whereas the former constitution expressively named government sessions as the decision making forum of the government, the Fundamental Law does not include the concept of government session, and does not refer to this term. The "constitutional minimum" of corporate functioning was replaced by the level of government decision. The strengthening of the Prime Minister's powers as opposed to corporate characteristics is also indicated by the fact that upon authorisation by the Rules of Procedure, if it is especially necessary, the Prime Minister

16 Article 16 of the Fundamental Law: "(1) The members of the Government shall be the Prime Minister and the ministers. (2) The Prime Minister shall appoint one or more deputy Prime Ministers from among the ministers by means of a decree. (8) The Government is considered formed upon appointment of the ministers."

17 Article 18 paragraph 5 is carried out and the more effective functioning of the Government is aided by the Ksztv. The detailed rules of the functioning of the Government are laid down in the Rules of Procedure of the Government [see Government decision 1144/ 2010. (VII.7.)]. 
can - on his own right - issue government decrees when the Government is not in session. ${ }^{18}$ Besides constitutional changes, the diminishing of corporate character is also indicated by the decreasing number of formal government sessions, and the increasing number of informal consultations and informal government sittings. ${ }^{19}$

The Government holds sessions regularly - weekly - as set forth in its half-year timetable with monthly timing. The Rules of Procedure describes the regulations for preparing government sessions, it sets forth that every motion and report submitted to the government session has to be discussed first at the session of the Ministers of State for Public Administration ${ }^{20}$ Ministers, have to be present in person, in the case of hindrance the appointed state secretary is allowed to substitute, and if he also cannot be present, the Minister of State for Public Administration takes part in the session, without voting rights. The list of invited persons is described in the Rules of Procedure; the Head of the National Bank has to be invited whenever the Government session deals with a case within his authority. The Government has a quorum if more than half of its members are present. Government members have equal voting rights, decisions are made with majority of votes; in case of unanimous decision the Prime Minister's vote decides. In fact the Government does not make its decisions with a majority and a formal voting procedure; there is no chance to outvote the Prime Minister. The Prime Minister chairs Government sessions, and he calls the decisions made in the session. Despite all this the Government should not become the forum that confirms the decisions of the Prime Minister, because for Government decisions, the whole government, therefore each minister is responsible to the Parliament.

\section{THE STRENGTHENING OF THE GOVERNMENTAL CENTRE}

The Government may form cabinets that are entitled to give an opinion before Government sessions in important issues of social, economic or national security policy. Members of the cabinets are the ministers, affected and other persons appointed by them. The Government may form a Government panel in order to coordinate any significant tasks that fall in the purview of multiple ministries. Failing an Act of Parliament or a Government decree, the cabinet and the government panel has no decision making authority. The Government - by a normative decision - may appoint a Government commissioner in order to fulfil tasks that do not fall within the purview of any ministry. A minister, an undersecretary, administrative undersecretary, deputy undersecretary, or any other person that does not fall into the above mentioned categories may be appointed in order to carry out a task that falls within the purview of the Government. The Government commissioner's work is supervised by the Prime Minister; he may be appointed for a finite period of a maximum of two years.

18 "The Prime Minister between sessions of the Government - in a case of urgency - may issue a Government decision in cases of delegating tasks, carrying out international negotiations and signing agreements, organising visits, in some cases of appointments and dismissals, and in giving decorations; furthermore in other cases - by authorisation of the Government - he may issue Government decrees and decisions. (Rules of Procedure, point 77.).

19 Mandák (2012) 30-41.

20 The Session of Ministers of State for Public Administration is a preparatory, administrative coordinating and supervising forum created after the system change. The most important participants of this session are the Ministers of State for Public Administration, but there are several other invitees of the Conference. The Rules of Procedure of the Government decides on the list of people to be invited. 
The Prime Minister may appoint a Prime Minister's commissioner by virtue of a normative order to carry out a task within the Prime Minister's authority. The Prime Minister's commissioner may be entitled with controlling powers by virtue of a Prime Minister's decree; his mandate lasts until the termination of the Prime Minister's mandate. The Government may create other initiative or consultative bodies.

The Prime Minister's Office, which - by the Act XX of 2014 on the ministries of Hungary - have been given the rank of the ministry that coordinates the Government's work, has great importance concerning the functioning of the entire Government. The Prime Minister's Office, ${ }^{21}$ which first functioned as the Prime Minister's working body, became responsible for governmental coordination, has lately also taken the place of the former Ministry of justice and public administration, thus turning into a "super-chancery". After the election of 2010 the former Prime Minister's Office, as a Government agency ceased to exist, and most of its competences were integrated into the Ministry of justice and public administration. By turning the former Cabinet Office into the new Prime Minister's Office, a new Government organisation was created. After the election of 2014 the justice functions were separated and the supreme body of Governmental coordination was re-created as a ministry, the leader of which has the rank of Minister. ${ }^{22}$ The founding document of the Office of the Prime Minister lists 17 competences that fall within the tasks of the Minister of the Prime Minister's Office. ${ }^{23}$ The statute defines the Prime Minister's Office as the working organisation of the Minister of the Prime Minister's Office, which is special administrative body, supervised by the Government. The new regulation brought significant changes to the legal status and the duties of the Prime Minister's Office. As for its legal status, the Act on the ministries of Hungary removes it from other ministries, as the Ministry primarily responsible for governmental coordination. In the period between 2010-2014 the Prime Minister's Office was the working organisation of the Prime Minister. It was led by an undersecretary, and its main function was defined as assisting the Prime Minister and participating in the formation of the Government's general policy. Therefore, according to the new statute, it is no longer the working body of the Prime Minister; however it is still directly supervised by the head of government. Out of its especially wide competences, consisting of several special policy areas, the dominant characteristic is the task of coordinating Government policy and the strategic leading of the public administration.

21 "The basic institution of the indeed chancellor-like, personified governing is the Government "flagship", the Prime Minister's Office, which the people started calling chancery... as in 1998 the PMO of the Orbán government means the shifting of government structure towards a chancellor system, in 2002 it became more founded to say that the PMO that organised its own structure became a special kind of top ministry within the Government, which is indicated by the solution unknown in Western democracies that the minister leading the PMO became the general deputy of the Prime Minister." Sárközy (2012) 241-242.

22 The Prime Minister issued the founding document of the Prime Minister's Office based on Article 8 of Act CXCV of 2011 on the Public Finances in 24 July 2014.

23 These are the following: coordination of Government activities, quality management and personnel policy of the public administration, development of public administration, organisation of public administration, legal supervision of local governments, use of EU funds, agricultural and rural development, research and development and technical innovation, public procurement, development policy, protection of cultural heritage, development of settlements, coordination of civil intelligence services, postal functions, coordination of social policy, coordination of science policy, coordination of governmental PR, carrying out public policy research, incorporating Hungarian and international experiences, and other preparatory services. 
By interpreting the statute and the Rules of Procedure together, the Prime Minister's Office is actually the Prime Minister's working organisation in a broad sense. ${ }^{24}$ In the Prime Minister's Office nine secretaries - among them one Minister of State for Public Administration - and almost thirty deputy secretaries assist in the work of the Government. According to the portfolio and the new ministry status of the Prime Minister's Office the "chancery-minister" leading the Office has a stronger legal and political power than any of his predecessors. The Prime Minister is aided by a large professional apparatus in determining the general policy of the Government, exercising professional and political oversight over the public administration, and in managing daily duties of governing. The new profile of the "chancery" integrated in itself several strategic policy areas (agricultural development, European Union development areas, national financial services, the post, local public administration), therefore becoming a sort of "government in the Government". So there was a paradigm shift in the functioning of the Prime Minister's Office. From the working organisation of the Prime Minister, it became a Governmental power centre with a broad range of competences, and thus the main holder and primary basis of the centralised power of the head of government. The power of the Prime Minister, which was strengthened by the Fundamental Law, is aided by an institutional structure that holds in itself the seeds of turning into a presidential system.

In the preparatory phase of the Government's decision making process, and in coordination with the functioning of the public administration, the Session of Ministers of State for Public Administration plays a key role. This session is the Government's general preparatory organisation; every proposal that goes to a Government session has to be discussed by this session first. The Session of Ministers of State for Public Administration is summoned by the Minister of State for Public Administration of the Prime Minister's Office; he is also responsible for the schedule of the CAU. In the period 2010-2014, together with the weakening of the coordinative role of the Ministry of Justice and Administration, the preparatory role of this session has also diminished. In many ways the most important forum of professional and political discussions became the Session of Parliamentary State Secretaries that was led by the Parliamentary State Secretary of the Prime Minister's Office. In the new role of the Prime Minister's Office after the elections, the traditional administrative preparatory role of the Session of Ministers of State for Public Administration may become more appreciated.

\section{THE GOVERNMENT AND THE CENTRAL ADMINISTRATIVE BODIES}

According to Article 1 paragraph 2 of the Ksztv. central administrative bodies are: the Government, Government committees, the ministries, the autonomous administrative bodies, Government agencies, law enforcement agencies, the Military National Security Service, and autonomous regulatory bodies. ${ }^{25}$ In this paper the focus is on the role of ministries and autonomous administrative bodies.

${ }^{24}$ This is pointed out in Article 8 of the organisational regulations describing the tasks of the Minister of the Prime Minister's Office: "he sees to the carrying out of the tasks defined by the Prime Minister" and "he participates in the public policy founding of the Prime Minister's decisions and in carrying them out".

25 Autonomous administrative bodies are the Office of Public Procurement, the Equal Treatment Authority, the Hungarian Competition Authority, the National Authority of Data Protection and Freedom of Information, and the National Elections Office. Government offices are the Central 
The election of 2010 brought the most radical change of Government structure in the past twenty years. ${ }^{26}$ In the Hungarian constitutional system the Prime Minister has - especially if there is no coalition's political pressure - a really wide range of motions to create the structure of ministries. Regulations of the Fundamental Law make it clear ${ }^{27}$ that a ministry may only be created by an Act of Parliament, the adaptation of which requires only a simple majority. The structure of the Government represents the political priorities of the Government, emphasizing the importance of various fields. In a balanced political arena the opposition does not challenge the right of the governing majority to fit the Government's structure to its political views. The ministerial structure laid down in Act XX of 2014, with minor changes it preserved the main characteristics of the governmental re-shaping carried out four years earlier. ${ }^{28}$ The Act differentiates between the Office of the Prime Minister as a ministry responsible for governmental coordination, and other ministries responsible for a specific policy field. The change in the name of the four ministries (Ministry of Human Resources, Ministry of Agriculture, Ministry of Justice, Ministry of Foreign Trade and Foreign Policy) is in connection with the change of function and with the purpose of making a more specific profile for the ministries. The structure of grand ministries was broken by the establishment of separated ministry of justice and by the clarification of the agricultural affairs, but the basic model of grand ministries has not changed. The "super chancery" Office of the Prime Minister has been arise above other ministries.

The legal regulation of ministries is based on the Act on the organisation of the Government (Ksztv.), which not only defines the organisational structure of ministries, but, quite oddly, it gives a definition for ministries as well. The ministry - as the working organisation of the minister - is a Government controlled central administrative body having specialised tasks. It is a top level Government office with decision making privileges, which carries out the continuous management of state matters in specific policy areas. ${ }^{29}$ The minister controls the ministry and in this competence he oversees the work of Ministers of State for Public Administration and Parliamentary State Secretaries. The minister, the Ministers of State for Public Administration, Parliamentary State Secretaries deputy

Statistical Office, the National Nuclear Energy Authority, the Hungarian Intellectual Property Office, and the National Tax and Customs Administration. Law Enforcement Agencies are the police, the staff of the correctional facilities, the professional disaster prevention authority and the civil national security services. Autonomous regulatory bodies are the National Media and Infocommunications Authority, the Hungarian Energy and Public Utility Regulatory Authority.

${ }^{26}$ By significant decrease of the number of ministries eight integrated ministries have been formed: Ministry of Justice and Public Administration, Ministry of Interior, Ministry of Defence, Ministry of Foreign Affairs, Ministry of National Economy, Ministry of National Resources, Ministry of National Development, Ministry of Rural Development. See more: Smuk (2011) 367-369.

27 According to Article 17 of the Fundamental Law: "(1) The ministries shall be listed in an act of Parliament. (4) The provisions of an implementing act regarding the designation of ministries, ministers or administrative bodies may be amended by an act of Parliament."

28 According to Article 1 of the Act on the ministries of Hungary: "the ministries of Hungary are the Prime Minister's Office as a ministry with the primary function of governmental coordination and the ministries of special policy areas. The ministries of special policy areas are: Ministry of Agriculture, Ministry of Defence, Ministry of Foreign Affairs and Trade, Ministry of Human Capacities, Ministry of Interior, Ministry of Justice, Ministry of National Development, Ministry for National Economy".

29 Petrétei (2013) 162. 
secretaries are state leaders. Within this group the minister and the Parliamentary State Secretaries qualify as political leaders, while the Ministers of State for Public Administration and the deputy secretary are administrative leaders. The biggest difference between political leaders and administrative leaders is that the mandate of political leaders is connected to the mandate of the Government, while the appointment of administrative leaders is for an unspecified period, is not in connection with the Government's mandate. ${ }^{30}$

The Government specifies the detailed tasks and competences of the minister in a decree. ${ }^{31}$ The position of a minister is not only a Government position, but it is a politician's status, in which case political accountability and confidence plays an important role. Besides the professional accomplishments, his work is evaluated in a political way each time he is present in front of the Parliament. As the task of a minister without portfolio includes only such tasks that can be specified that do not fall into the authority of any ministry. It is important that the minister may appoint a Minister's Commissioner in order to carry out a task within the Minister's purview. ${ }^{32}$ The Fundamental Law differentiates between a minister leading a ministry and a minister without portfolio. ${ }^{33}$ The minister is nominated by the Prime Minister and is appointed by the President. The mandate of the minister is dependant on the Government's mandate. Article 20 of the Fundamental Law specifies the cases when the mandate of the minister is terminated; the mandate of the minister ceases: a) when the Prime Minister's mandate is terminated, b) if the minister resigns, c) if the minister's mandate is revoked, d) if the minister dies.

The state secretaries are among the main leaders of a ministry. The secretary - with the exception of a few cases - is the full deputy of the minister. The secretary oversees the work of the deputy secretaries. The Act does not specify the number of secretaries. The secretary is nominated - after discussing it with the minister - by the Prime Minister, and is appointed by the President. The mandate of the secretary is terminated by the termination of the Prime Minister's mandate, by resignation, by revoking his mandate, and by his/her death. The secretary is accountable towards the Minister and the head of Government for his exercise of powers.

30 The minister and the undersecretary are politicians and in this capacity they form the Government policy, take part in main Government decisions, and make their choice between policy alternatives based on political weighing of choices. In fact, administrative positions often get politicised, the politicising of public administration is a world phenomenon, therefore government changes often affect a larger group than actual political nominees. See: Stumpf (2011).

31 Decree 152/2014. (VI.6) on the tasks of the members of the Government.

32 The appointing powers of the minister are limited. First he has to inform the administrative undersecretary of the Prime Minister's Office, who may exercise his veto privileges, provided for by Article 71 of the Ksztv.

33 According to Article 18 of the Fundamental Law: “(2) The minister shall - within the framework of the general policy of the Government - autonomously run the sectors assigned under his or her competence, including the subordinate bodies, and perform the tasks assigned by the Government or the Prime Minister. (3) Members of the Government shall have authority to issue decrees under authorization by an act or government decree, in the performance of their respective duties, at their own discretion or in agreement with another minister. Such decrees, however, may not be contradictory to any act or government decree, or any decree of the Governor of the Hungarian National Bank." According to Article 17 of the Fundamental Law: "Ministers without portfolio may be appointed to perform specific tasks determined by the Government". 
The Ministers of State for Public Administration leads the office apparatus of the ministry, and oversees the work of deputy secretaries. Only one Minister of State for Public Administration may be appointed in each ministry. The Minister of State for Public Administration - unlike the secretary - is the administrative-professional leader of the ministry. Also appointed by the President of the Republic, but his appointment is for an unspecified duration. So the mandate of the Minister of State for Public Administration is not dependant on the Government's mandate, but because of the political influence on the public administration, this post is often replaced when a new government takes office.

The operative leading of the policy work of the ministry is done - under administrative oversight by the Minister of State for Public Administration and policy instructions of the secretary - by the deputy secretaries. Deputy Secretaries are appointed by the Prime Minister upon the nomination by the minister. The Secretary may control the work of several deputy secretaries, and deputy secretaries may also function under the oversight of a Government's Commissioner. The deputy secretary is deputised by a Head of Department under his authority.

The gaining of ground by independent regulatory authorities is related to the strengthening of the state's economic involvement. Modern public administration often steps outside of the traditional role of administrative authority and undertakes legislative tasks as well. This new role breaks with the logic of the separation of powers, because an administrative body, belonging to the executive branch, also has sui generis legislative functions; there is no administrative remedy against their decisions, however their decisions may be challenged at court. They carry out their tasks, mostly regulated by an Act of Parliament; independently form the leaders of the executive branch. The leaders of the autonomous regulatory authorities are mostly appointed by the Prime Minister or by the President for a finite period, and there is no option to revoke their mandate. Autonomous regulatory authorities are mostly found in the field of financial administration, media administration and in the energy sector.

Article 23 of the Fundamental Law, unlike the former constitution, has elevated the autonomous regulatory authorities to a constitutional level. ${ }^{34}$ The Fundamental Law only created framework regulations, and made it the Parliament's sphere to establish these bodies via cardinal statutes. According to the most important constitutional regulations, only the Parliament can create autonomous regulatory authorities by cardinal statute, in order to carry out specific tasks within the purview of the executive branch. By authorisation of an Act of Parliament, the leader of an autonomous regulatory authority may issue decrees. The head of the autonomous regulatory authority has to present a yearly report to the Parliament, and receives his mandate from the Prime Minister or the President for a finite period of time. Both accountability rules and the rules of appointment strengthen the independence of

34 "(1) Parliament shall have authority to establish autonomous regulatory agencies in an implementing act for carrying out certain tasks and exercising certain competencies of the executive branch. (2) The heads of autonomous regulatory agencies shall be appointed by the Prime Minister, or by the President of the Republic on a recommendation by the Prime Minister, for a period specified by an implementing act. The heads of autonomous regulatory agencies shall appoint their deputy or deputies." [Article 23. of the Basic Law]. 
these bodies. In parliamentary democracies autonomous regulatory authorities appear as a limitation to the centralisation of Government powers, and in some areas they limit the manoeuvring space of the Government. ${ }^{35}$

\section{SUMMARY}

The aim of this paper is to show the change in the constitutional situation of the Government by describing the regulations of the Basic Law and comparing them to the previous Constitution. This way the double function of the Government and the role of the Prime Minister are emphasized. The paper concludes that the presidentialisation of politics affects the role of the Prime Minister within the Government. Among the causes of this process the paper nominates the weakening of traditional social breaking points, the re-composition of the role of the state, the globalisation of politics, and the appreciation of mass communication. Among the most important points of presidentialisation the paper discusses the widening of the powers of the head of government, the centralisation of political processes and Government communication, and the strengthening of the supervisory role of the Prime Minister's Office. The position of the Government, as a corporate type body, is discussed through presenting its relationship with the Parliament. The relationship of various administrative bodies and the Government is presented via the radical government reform after the 2010 election, and it is concluded that the Prime Minister has great freedom in creating the ministerial structure. The ministerial structure reflects the policy priorities of the Government by emphasizing specific policy areas. One of the most important changes in the constitutional regulations was the appearance of regulatory authorities and bodies. The appreciation of these bodies may be explained with the strengthening of the Government's economic role: the modern public administration must step out from the traditional framework of administration, and must be given legislative powers in its new role.

\section{LITERATURE}

Bihari, M., Magyar politika 1944-2004. Politikai és hatalmi viszonyok [Hungarian politics, 19442004. Political and powerful relations] (Osiris Kiadó 2005).

Fazekas, J., 'Central administration' in A Patyi and Á Rixer (eds), Hungarian Public Administration and administrative Law (2014) 287-303.

Hine, D., Governing Italy 'the Politics of Bargained Pluralism' (Calderon Press 1993).

Jakab, A. (ed), Az Alkotmány kommentárja I-II [Comment on the Constitution] (Századvég Kiadó 2009).

Kukorelli, I., Tradició és modernizáció a magyar alkotmányjogban. [Tradition and modernization in the Hungarian constitutional law] (Századvég Kiadó 2006).

Mandák, F., 'A magyar kormányzati struktúra reformja a második Orbán kormány idején' [Reform of the Hungarian governmental structure during the second governmental period of Orbán] in I Verebélyi (ed), Az állam és jog alapvető értékei a változó világban (Győr UP 2012) 30-41.

Müller, Gy., Kormányról kormányra a rendszerváltás utáni Magyarországon [Hungarian Governments after the transition] (Magyar Közlöny és Lapkiadó 2008).

35 Based on its constitutional privileges the Parliament created two autonomous regulatory organisations: the National Media and Info-communications Authority (see Act CLXXXV on media services and mass communication), and the Hungarian Energy and Public Utility Regulatory Authority (see Act XXII of 2013 on the Hungarian Energy and Public Utility Regulatory Authority). 
Petrétei, J., Magyarország alkotmányjoga II [Hungarian constitutional law II] (Kodifikátor Alapítvány 2013).

Poguntke, T., Webb, P., Presidentialization of politics: a comparative study of modern democracies (Oxford University Press 2005).

Sárközy, T., Magyarország kormányzása 1978-2012 [Governments of Hungary 1978-2012.] (Park Könyvkiadó 2012).

Stumpf, I., Erös állam - alkotmányos korlátok [Strong state - constitutional limits] (Századvég Kiadó 2014).

Stumpf, I., 'Rule of Law, Division of Powers, Constitutionalism' (2014) 4/55 HJLS 299-317.

Stumpf, I., 'Stabilitás és „zsákmányrendszer” szerepe a közszolgálati életpályában' in M Gellén (ed), Új feladatok-átalakuló közszolgálat. Tanulmányok a II. Magyary Zoltán emlékkonferencia kapcsán (Nemzeti Közigazgatási Intézet 2011) 19-24.

Smuk, P., Magyar közjog és politika. 1989-2011 [Hungarian public law and politics] (Osiris Kiadó 2011).

Térey, V., 'A kormány’ [The government] in L Trócsányi, B Schanda (eds), Bevezetés az alkotmányjogba (Budapest 2010) 261-284. 